\title{
Religious Faith as Cultural Heritage at the Refuge for World Truths
}

\author{
Aaron Raverty \\ Saint John's Abbey and the Collegeville Institute for Ecumenical and Cultural Research, Collegeville, \\ MN 56321-2015, USA; araverty@csbsju.edu
}

Received: 27 February 2020; Accepted: 17 April 2020; Published: 21 April 2020

\begin{abstract}
Faith undergirds the Refuge for World Truths, a multireligious heritage-scape that emerged out of an old Spanish land grant adjacent to the Wild West mining and ranching town of Crestone, Colorado. Established by an entrepreneurial husband-and-wife team in the late twentieth century, the Refuge's spiritual centers were founded upon different faith commitments. Christian, [Sufi] Muslim, and Baha'i centers adhere to a monotheistic faith and claim divine revelation as the source of their presence in the Refuge. New Age, polytheistic, and nontheistic groups base their faith claim on the personal mystical revelations of "Glenn," a local peripatetic and self-described prophet who hailed the arrival of the original couple. Two stints of ethnographic research point to the spiritual centers' public ritual performances as both invitations to pilgrims to intensify this faith and as functional cogs in the integration and continuity of the heritage-scape's ritual economy. Finally, the faith expressions underlying the Refuge for World Truths allow this unique locality to champion interreligious dialogue as a method for addressing diversity and negotiating potential onsite conflict on the path to peaceful mutuality.
\end{abstract}

Keywords: brand; faith; heritage; interreligious dialogue; revelation; ritual; tradition

\section{Introduction}

Faith undergirds heritage in the Refuge for World Truths. This unique conglomeration of religious centers in rural Colorado-a heritage-scape (Di Giovine 2009)—was a destination for spiritual seekers and a site of two stints of ethnographic field research. But something is missing by limiting it solely to an ethnographic project without considering the overarching theological and cosmological rationale-faith commitments-that remains integral to its founding.

In the recent past and on the contemporary scene, the religious quest among spiritual pilgrims has taken different paths. One place where such issues of faith and heritage have become highlighted is at the Refuge for World Truths in the San Luis Valley of south-central Colorado. Faith as a frame of reference is a good starting point. But how can the study of faith be operationalized when we lack direct access to subjects' inner dispositions? As we will see, an estimate of faith can be garnered at the Refuge for World Truths through documentation of participants' dedicated public display of ritual devotion. ${ }^{1}$

1 A partial list of organizations establishing the Refuge for World Truths as of 2014 were: Atalanta (Network; Ecosystemic Harmony); Baha'i (Network); Chamma Ling (Bön Tibetan Tradition); Crestone End of Life Project (CEOLP); Crestone Mountain Zen Center (Zen Buddhist); Dances for Universal Peace/Wonder Bob (New Age); Dharma Ocean Foundation (Tibetan Buddhist); Dragon Mountain Zen Temple (Zen Buddhist); Haidakhandi Universal Ashram (Hindu Ashram); Humanity in Unity (Temple of Consciousness; Ashram of H.H. Sai Maa); Jangchub Chörten Stupa Temple of Enlightenment (Pundarika Foundation, Tibetan Buddhist); Karma Thegsum Tashi Gomang (Tibetan Buddhist); Little Shepherd of the Hills (Episcopal Church); Mangala Shri Bhuti (Tibetan Buddhist); Nada Hermitage/Spiritual Life Institute (Catholic Carmelite); Nur Ashki Jerrahi Sufi Circle (Sufi, Islam); Oniyan Wakan Tipi (Native American/Lakota); Sacred Passage and the Way of Nature Fellowship; Shumei International Institute (Neo-Shinto Japanese); Sri Aurobindo Learning Center (Hindu/Indian); Subud San Luis Valley (SLV) (Indonesian Sufi/Islam); Vajra Vidya (Tibetan Buddhist); White Jewel Mountain (Tibetan Buddhist); Yeshe Khorlo (Tibetan Buddhist). 
The argument here is that the tensions arising from otherwise irreconcilable differences in the variety of religious meanings held by the stakeholders in the Refuge for World Truths were and continue to be minimized and managed (1) by faith in the presumption of theistic revelation and subsequent confirmation, and (2) by faith through prophetic human agency in the onsite interorganizational promotion and practice of interreligious dialogue for harmony and peace.

This is an especially timely argument for addressing both the hateful and indeterminate aspects of the global world in which we find ourselves, often as victims: of war, including both national and international conflict; and the largely unpredictable forces of nature: fires, earthquakes, floods, and the rampage of uncontrollable disease.

After briefly introducing the setting and history of the Refuge for World Truths, faith will be explored as a founding principle for the spiritual centers comprising this unique heritage-scape. The ethnographic research methods-assumptions and techniques-will then be outlined. Next, three brief instantiations - an emic and etic exploration —of ritual enactments will be presented, followed by a discussion of how a panoramic overview of the Refuge's public ritual performances reveals its function as a "ritual economy." Finally, this will take us to a reflection on why the Refuge for World Truths embodies a "sanctuary" for engaging in interreligious dialogue.

\section{The Setting: A Brief Overview and History of the Refuge for World Truths}

As a specific geographic arena embracing the spectrum of New Age and heritage foundations, the Refuge for World Truths was the site of two stints of my ethnographic research (1980-1981 and 2011). An old Spanish land grant was the original entity out of which the Refuge for World Truths emerged in the late twentieth century. The grant itself was perched atop an arid but scenic Alpine expanse in the San Luis Valley of south-central Colorado, adjacent to the old mining and ranching town of Crestone, wavering in elevation between 8000 and 9000 feet and nestled in the foothills of the Sangre de Christo mountain range. In the nineteenth century, sporadic miners gleaned the landscape in search of precious metals, especially gold. When gold fever diminished, the land passed through several owners who were very successful cattle ranchers, an occupation well suited to the area's topography and vegetation. After a round of subsequent purchases by a few logging, mining, and real estate development companies, it was finally procured by a husband-and-wife team with considerable business acumen, United Nations experience, and multiple international connections. They marked off part of the old grant for real estate development and the establishment of a retirement community (the Baca Grande), but they set aside some of the area to accommodate an influx of religious, spiritual, ecological, and "think-tank" communities, which eventuated in what they finally christened as the Refuge for World Truths, "an emergent global social imaginary that may amount to the reenchantment of the world" (Csordas 2009, p. 2).

\section{Faith as Foundation for the Refuge for World Truths}

Faith in its most basic theological sense marks assent to a religious commitment. From the Christian perspective, an important aspect is summarized in this scriptural passage: "Faith is the assurance of things hoped for, the conviction of things not seen" (Hebrews 11:1). "Religious commitment is generally understood as a deliberate identification with the teachings and practices of a particular tradition. It thus entails assent to the truth-claims of a particular tradition and recognition of the authority of the tradition in matters of doctrine and discipline" (Cornille 2008, p. 66). Faith, as the above passage from Hebrews implies, also involves revelation. Revelation, in turn, implies agency-in this case, a personal source who reveals. Christianity, Islam, and Baha'i all lay claim to the authority invested in a supernatural agency-God-who reveals the deity's will to human beings. But such 
theological faith as embodied at the Refuge for World Truths was always considered to be tempered by human reason. ${ }^{2}$

Lest we consider faith as little more than assent to an ideology—an abstract collection of existential and normative postulates-we need to realize that a faith commitment involves a much more personal and holistic orientation. After all, martyrdom points to the fact that one possesses the wherewithal to sacrifice even one's very biological existence for an overarching commitment to something or someone. Faith could be construed as one of the "primordial attachments" described by anthropologist Geertz (1973, p. 259).

This assertion is reinforced by prescinding from the exclusively religious or spiritual implications of faith and by casting it in a secular light. In his book Science, Faith and Society, philosopher Polanyi (1964) makes the case that scientific inquiry too is predicated on a "faith" commitment in the empirical, the a priori assumption that reality presents itself directly as it does to our senses and to our experience. Here, faith stands as epistemology. Faith, it seems, is universal-a stance that all humans must concede at some level to avoid the dead end of pan-skepticism. Moreover, through enculturation, we are all limited in our "faithful" view of reality by the imposition of "culture-tinted" lenses. "The anticipatory conceptions used in dogmatic speech are lenses through which we glimpse the transcendent" (Dulles 1983, p. 227).

Religious faith at the premier heritage site of the Refuge for World Truths had both vertical and horizontal aspects. Among those spiritual centers claiming a monotheistic (vertical) perspective (the Nada Hermitage/Spiritual Life Institute [Catholic Carmelite], the Nur Ashki Jerrahi Sufi Circle [Sufi, Islam], Subud San Luis Valley (SLV) [Indonesian Sufi/Islam], and the Baha'i network), the prevailing assumption was that faith in God had opened a "window of revelation" whereby the Deity revealed to the organizers God's desire to establish themselves amid this heritage site, proclaiming God's confirmation through public ritual display, and providing the raison d'être for the group's settlement. The resident polytheistic, nontheistic, and New Age spiritual groups also operated according to their "faith" (on a more horizontal plane) in the revelation of the local "old prophet" Glenn, heralding the "ideological entrepreneurs" who established the heritage-scape (Di Giovine 2009) in the first place-a site that would provide a unique arena for dialogue in diversity and the subsequent promotion of harmony and solidarity in an otherwise unpredictable and conflict-riddled world.

For the monotheistic (including trinitarian) traditions at the Refuge-Christianity, Islam, and Baha'i-faith implies revelation: "God is viewed as the divine visitor, the guest of the soul. He communicates by his presence, to which the recipient must be prayerfully open" (Dulles 1983, p. 33). Faith also implies salvation, the sense of being lifted beyond the current unsatisfactory circumstances through the personal agency of one-in this case, a Deity-who reveals the divine will to human beings. This revelation may come through prophets who, amid the Refuge for World Truths, could be those initiating and organizing the monotheistic spiritual centers and who supervise the ritual enactments interfacing with the public. The point is that faith, revelation, and salvation all have their ultimate origin in a singular and almighty God.

The New Age, polytheistic, and nontheistic traditions ensconced in the Refuge for World Truths, including the husband-and-wife team of "ideological entrepreneurs" who initially extended invitations to the various spiritual groups, were operating through a different stance of faith: the mystical writings, cosmological musings, and prophetic pronouncements of "Glenn" rather than from the personal agency of a single and almighty Deity. This type of faith "reveals by luring the imagination to construe the world in a new way. The recipients of revelation are those who dare to dream new dreams, responding to the call to build a fully human world" (Dulles 1983, p. 33), complete with its own form of salvation.

Such faith stands as one of the intangible components of heritage at the Refuge for World Truths. The "intangible packaging" of heritage is largely comprised of what Csordas (2009) labels

2 When carried to extremes, the assent of faith can morph into fideism, "the belief that faith is in some sense independent of or even adversarial toward reason ... [F]ideism is found, to some degree, in every major world religious tradition" (Moritz 2016, pp. 89-90). However, any further discussion of fideism need not concern us here since it was not characteristic of any of the Refuge's spiritual centers. 
"portable practices" and "transposable messages." At the Refuge for World Truths, these behavioral and communicative heritage components geographically comprise a heritage-scape (Di Giovine 2009) and emerge as brands ${ }^{3}$, largely through ritual performance.

Indeed, cultural heritage, like tradition, transmits its unquestioned authority from the past into the present and projects it into the future. In doing so, it venerates our beloved ancestors, as devotionally expressed in the Christian hymn "Faith of Our Fathers." "[H]eritage is a narrative that allows an individual to transcend his immediate past and present to connect with his predecessors, whom he feels to be unknown yet intimately a part of" (Di Giovine 2009, p. 35). Heritage acts as a rallying point around which people proclaim their ownership of a collective identity, a brand loyalty.

At the Refuge for World Truths, faith not only foregrounded pilgrim seekers' search, but it was also their goal. From a philosophical point of view, we might frame pilgrims' present-day spiritual quest as a matter of ontological security versus ontological exile: "There are many people today who are 'looking for something' that their own culture does not give them. These pilgrims of the Absolute have been touched by some intangible Reality, and they are restless until they can establish a more permanent relationship" (Casey 2005, p. 167). Theologian Karl Rahner spoke of this longing in his discussion, through the lens of Catholic theological anthropology, as the supernatural existential: the orientation of all human beings through the work of grace to the transcendent and to the person of Jesus Christ from the moment of their creation (Rahner 1976, p. 133). Something transempirical appears as part of the pursuit. People are looking for miracles-religious or otherwise-that will lift them out of their mundane existence. For some, museums and monuments may deliver similar "miracles."

During the decades of the 1970s and 1980s, under the influences of globalization, the creeping proliferation of new communications technology, and the dawn of social media, the spiritual search was largely embroiled in what anthropologist Wallace (1970, pp. 23-24) termed the "organization of diversity." In this context, "self was not necessarily an innate object to be developed, but instead multiple and open to various performances ... " (Cohen 2010, p. 39). Or, in the words of a contemporary dean of a Catholic school of theology: "We are awash in connections of all sorts, probably more than humans have ever known, yet we don't feel we belong and don't even know how to get started" (Cahoy 2016).

One of the upshots from this disarticulated (and admittedly romanticized) conundrum of spiritual options was the emergence of the New Age movement. Although the ideological boundaries of this social movement are diffuse and permeable-thus defying any neat definition-New Age thought and practice seeped into politics, economics, ecology, and other cultural domains (see Raverty 1990, chp. 2). But it had an especially profound effect on religious organization and spiritual search. "The concept of searching for self, a form of identity work, was frequently cited among the lifestyle travelers as a motivating factor for their engagement in lifestyle travel" (Cohen 2010, p. 37).

The rationale behind New Age thinking is what can be called the "amalgamation mindset":

We need to see that, although the parts of any cultural system are interrelated and mutually reinforcing, resisting change, we can learn those relationships and make thoughtful changes in our own system by incorporating parts of many cultures without buying the whole package of any one. We can recognize and even adopt the valuable perceptions and conventions of other cultures much as we selectively borrow their art or inventions, without having to adopt the entire lifestyle .... . (Cohen 1998, p. 135)

Those who embraced the New Age calling were prone to amalgamate elements from different religious traditions to create a personal "designer religion" to suit their individualism, sanction their interiority, and anchor their identity (e.g., the I Am Harmony homestead below). A New Age enthusiast's firsthand account of the process exposes this motivation: "The principles of selection

3 The intention here is not to "reduce" religion to a static brand designation, but (as we will see later) to heuristically exploit this marketing term as a conceptual handle to account for the dynamic in situ organization and function of the Refuge for World Truths. 
are my own tastes and preferences, as shaped by what surrounds me. What I omit or disregard is the earlier embeddedness of these objects in a set of traditions, practices and values, many of which could potentially challenge or disrupt my own" (Bregman 2016). Part of the tension at the Refuge for World Truths, however, was expressed in the competing claims to faith among those devotees drawn to a New Age vision over against those devotees who clung to heritage in well-established historical/ethnic spiritual traditions: "Modern multiculturalism and global exposure to multifarious values is increasingly challenged by fundamentalist movements to revive primary group loyalties through greater ritual commitments to ideological purity" (Atran 2012). With heritage, the goal of the spiritual quest is to authenticate (rather than amalgamate).

[C]ultural authenticity fundamentally implies continuity with historical cultural identity and values. To be "authentically" [religious/spiritual] is to be true to one's roots; to be able to trace a long and consistent biological, territorial, cultural and linguistic heritage; to exhibit distinction in ethnic practice; and to live in a culturally valued manner ... . (Wroblewski 2014, p. 75)

Thus, the model New Ager (or religious bricoleur; see Lévi-Strauss 1962) creates a spiritual outlook by amalgamation, while his or her counterpart seeks authentication in heritage.

Even avowedly peaceful and nontheistic traditions like Buddhism struggle to return to authenticity in the wake of New Age infiltration. Notice the defense of "faith" embodied in the heritage authority of the "lineage principle" of the Vajrayana vehicle as explained by a Tibetan Buddhist reborn adept (rinpoche):

Vajrayana is very different from the New Age approach. The difference is that the Vajrayana teachings are controlled by the lineage ... When we have this pure lineage, this genuine lineage, there is no space for our egocentric interpretation of dharma ... We cannot invent a new lineage because a lineage must be received. It must be received by transmission. It is not something we can just create here. That would be New Age ... . (Rinpoche 2014, p. 18)

The individual and collective slippage into a sense of transcendental homelessness (Berger et al. 1973) and a disturbing trend toward normlessness are all too evident in recent newscasts showing perpetrators and demonstrators engaging in violence on a previously unprecedented scale. Terroristic activities, both domestic and international, are on the rise, disrupting the former predictability - the taken-for-granted mutual expectations—of everyday human social life. The spiraling away from spiritual (and moral) anchors-what anthropologist Clifford Geertz described as primordial attachments (Geertz 1973, p. 259)—seems more and more a mark of the contemporary scene.

In the search for authenticity amid this relative chaos, the parallel search for an anchor in brand security does not seem all that out of place. "[A]ccording to brand logic, activities of consumption ideally reconstitute the brand and simultaneously allow consumers to experience their own individual authenticity" (González 2015, p. 18). Perhaps this is one reason why places offering a faith-filled transcendent mooring in a heritage tradition are such attractive destinations for spiritual tourism: "[A]s a supposed means of resisting pressures and dissatisfaction with one's home society, tourism has been regularly used in modern attempts to allow alienated individuals escape from the constraints of a perceived mundane existence and/or the anomie of Western society" (Cohen 2010, p. 29).

Di Giovine (2009, p. 352) notes that amid heritage settings, "Infrastructural improvements often bring tangible resources, enable communication and increase commerce. And especially when tourism is involved, they enable cross-cultural interaction." To create their imaginary, the founders of the Refuge for World Truths extended invitations to many diverse religious organizations and networks in addition to global, corporate think tanks, hoping that the offer of a gift of real estate for the purpose of erecting a chapel, temple, retreat, or conference facility would especially entice and seduce pilgrim transcendental seekers from a wide variety of backgrounds. In so doing, they unintentionally created-in light of contemporary "brand theory" - a type of place brand (McClinchey and Carmichael 2010). "New kinds of places are emerging that give more flexibility to a variety of religious and spiritual providers: Spiritual meeting centers and esoteric fairs have the advantage of not being centered on just one or two 
types of supply, and of acting as an open space in which many different suppliers may engage with various publics" (Stolz and Usunier 2014, p. 21; emphasis in original). Although some may balk at the notion of religions as "brands," others, citing methodological usefulness, regard it an apt descriptor:

There can be no doubt that branding as a concept is applicable to religious phenomena. Religions may be considered to have brand names: Christianity, Islam, Judaism, or Christian Science. They normally have signs that may well be interpreted as easily recognizable brand logos: The cross or fish for Christianity, the Yin-Yang sign for Taoism, the star and crescent for Islam, the Lotus flower for Buddhism, the star of David for Judaism. They have "brand stories" (myths) that are embodied in rituals, objects, works of art, buildings and clothing. Their places of worship are often built in a branded, i.e., recognizable, way representing churches, mosques or temples. (Stolz and Usunier 2014, p. 16; emphasis in original)

Considering this couple's unique agency in establishing such a multireligious and multicultural site, I have dubbed them "ideological entrepreneurs" (Raverty 1990). Indeed, from an eschatological perspective (from the point of view of the "end times"), the Refuge for World Truths assumes the contours of a modernist project "whose effect is to erect a new suprapersonal, transcendent and hence sacred canopy to provide a refuge from the subjective collapse of the cosmos into primordial meaninglessness" (Griffin 2012, p. 66). Perhaps another way to describe this entrepreneurial duo is as "heritage preservationists." One way to think about this in the context of a faith commitment is that "revelation takes place as an expansion of consciousness or shift of perspective when people join in the movements of secular history. God, for them, is not a direct object of experience but is mysteriously present as the transcendent dimension of human engagement in creative tasks" (Dulles 1983, p. 28).

Shortly after this couple arrived at the grant and set up a homestead, an old man considered a prophet by many of the residents in the area appeared at their doorstep unannounced, proclaiming to the woman that this couple's plan to establish a local heritage haven had been revealed and foretold to him in dreams and divinatory writings.

Revelation is seen as a divine summons to transcend one's present perspectives. Since this summons is always correlated with the actual situation as well as with the basic dynamism of the human spirit, revelation comes in new ways in each period of history. In our own day ... revelation involves a call to put aside the limitations of cultural self-centeredness and to be open to the working of the divine Spirit in alien cultures. (Dulles 1983, p. 187)

"Glenn," the old prophet, told them, "I have been waiting for you." The revelation from faith in Glenn had become incarnate in these new arrivals. The prophecy would be fulfilled in the heritage-scape of what was to emerge as the Refuge for World Truths.

\section{Methodological Assumptions}

As an anthropologist of religion, I approach this study of faith and heritage in ritual performance at the Refuge for World Truths first and foremost through ethnography. The "ethnographic gaze" begins from different vantage points. For those immersed as a participant within a religious performance, the "emic" (insider's subjective) perspective takes precedence. Observing and describing the material, spatial, gestural/behavioral, and linguistic aspects of ritual performance from a more objective and external point of view, constitutes the "etic" perspective (cf. the parallel phonemic and phonetic aspects of linguistic analysis). Whenever possible, ethnographers prefer to combine both "gazes" for the best fit. However, one can step back to adjust the focus of the ethnographic lens even more widely by overviewing an entire field of performative instantiations-a panorama, if you will—that yields a broad organizational gestalt of the action. After describing the specifics of three ritual performances at different sacred sites within the Refuge, I will apply this overarching perspective in my formulation of the "ritual economy." 
True to my anthropological training, participant observation and interviews in addition to informal meetings and conversations were the mainstays of my research methodology. The constant traffic of spiritual tourists and curiosity visitors to the Refuge for World Truths rendered it virtually impossible to delimit a more stable and well-defined population for sampling. Besides, most were visiting only temporarily to engage in the public ritual opportunities offered by the various spiritual centers. I was alert to the timing of such public rituals and arrived to witness both the "faithful" assembled and the performance itself. This was where the "real action" was focused; these sites and events generated the raw data requiring collection. These ritual settings and enactments also gave the Refuge for World Truths both a functional stability and continuity: a ritual economy.

However, given my training and perspective in theology, my methodology involved additional considerations and encompassed a larger frame of reference. Faith as a theological construct is not empirical, but the assumption of faith was integral to understanding and investigating all the possibilities of the Refuge for World Truths as a heritage-scape (Di Giovine 2009).

Ritual is human interface with the sacred based on a faith commitment. Ritual reconfigures space and alters or obliterates time altogether, in much the same way as the observer's absorption in a museum display or diorama. Ritual symbols have both sensory and ideological poles (Turner 1967). The sensory pole comprises material objects, substances, and sounds; the ideological pole comprises moral systems and philosophical elements such as the existential and normative postulates embedded in a worldview. As we will see in the examples below, the harmony of movement and gesture in a ritual performance mediates these polar extremes and expresses them in uniquely embodied ways.

Faith and heritage figure prominently in these rituals. Faith and heritage both showcase and fuel the ritual economy.

\section{Ritual Performances at Selected Sites at the Refuge for World Truths}

\subsection{Am Harmony}

Despite the growing desire to tap into ever-deeper layers of heritage religion, the Refuge for World Truths was not lacking in onsite New Age establishments. One of the most colorful examples was the I Am Harmony homestead site. Anchoring the site was a private residence offering bed and breakfast. Surrounding the residence was a "Garden of Love" strewn with sundry "features" —creative arrays of disconnected and seemingly frivolous elements-one could engage in different ways as one wandered the intertwining cobblestone pathways connecting them.

Although there were no agents or commodified ritual events seducing visitors into religious performances, the I Am Harmony homestead site lightheartedly enticed the inquisitive to create one's own performance by entering over the Bridge to Love to engage unique assemblages of diverse and flamboyant objects. For example, one was invited to "play" at several stations along the meandering path, much as a child who had stumbled across a treasure trove of toys titillating the imagination.

Meditation and prayer were encouraged at several of the stations, whereas others stimulated a more embodied participation. One stopping point was piled with toys that invited visitors (child or adult) to use their imaginations for playful interaction. A cache of agates, crystals, and other colorful rocks strewn in another patch of the garden invited participants to touch them, pick them up, or otherwise rearrange them to release the energy of their healing properties.

\subsection{Dragon Mountain Zen Temple Dharma Talks}

The performative outreach of this Zen Buddhist strawbale building complex at the Refuge for World Truths consisted of interactive "dharma talks" (Joskovich 2016). These were offered twice a month at the Dragon Mountain Zen Center by its ritual agents, the resident Zen abbot and his female administrative consort. A temple and administrative/residential units comprised part of the complex, but the ritual teachings took place in a Zen "dharma hall" replete with thangkas, Buddha images, a large drum, singing bowl, altar, fresh flowers, small silver water bowls, and incense. Those who came to 
listen to the talks were seated on zafus or chairs (depending on their comfort levels) in a semicircular configuration. They remained silent and receptive for the duration of the formal teaching (about an hour) after which participants were offered food and drink (usually cookies and tea), rearranged their seating to form a close-knit circle, and were then invited to ask questions and interact with the abbot, his consort, and with one another. The setting for the talks had a classroom feel in which the abbot, as presenter, seated himself on a zafu facing his audience. He held a small, wooden "staff" — signifying his teaching authority-with an embroidered cord hanging from one of its ends and a curvature on the other end, which he leaned on and manipulated during his "performances": "Like any good actor, the rōshi is required to completely identify with his part in order to convince the audience of its authenticity" (Joskovich 2016, p. 15). The number of participants was quite small and ranged anywhere from six to nine per meeting. The formal performative aspect of this ritual was bracketed by respectful bowing to the image of Shakyamuni Buddha and to one another prior to and at the conclusions of the sessions. What kinds of topics were covered in these dharma talks? At one of these sessions, as I recorded in my field notes, "[the abbot] read a poem from a Zen Buddhist author that started the discussion rolling ... [T] he discussion ranged widely and covered many topics, some more abstract (e.g., prophets and hermits; living alone and living in community; the value of service) and some personal (e.g., writing poetry)" (Raverty 2014, p. 142). The lively interaction in these dharma talk sessions and subsequent discussions - encompassing much of their performative dynamic-were largely the result of the background diversity of the participants. These talks clearly demonstrated that "it is possible to understand the sermon as both a symbolic representation of authority, as well as an arena for personal transformation .... Viewed in light of performance theory, the sermon demonstrates that ritualized actions and religious insight are not contradictory, but rather are interrelated and complementary, and that awakening might be best understood as a mode of activity, a form of bodily knowledge acquired, realized, and displayed through ritual performance" (Joskovich 2016, p. 4). It was not unusual at any one session for Christians, resident Sufis, other Zen Buddhist practitioners, and even self-proclaimed agnostics to count themselves among the "seekers" in attendance.

\subsection{Sufi Dhikr Ritual Performance}

Another public ritual performance at the Refuge for World Truths was a dhikr ceremony from the Sufi (Muslim) tradition. The word itself is Arabic and means "remembrance" or "liturgy." The ritual took place in a special room set apart in the home of one of the woman residents in the area who claimed to be an initiate of a female Sufi master in the Nur Ashki Jerrahi Sufi Circle. The dhikr was scheduled most Thursday evenings, and it was announced in advance in the local newspaper. Everyone was cordially invited. Prior to the dhikr, those assembled enjoyed a potluck dinner and table fellowship.

Upon arrival, participants removed their shoes at the entrance, a convention followed at most of the ritual sites at the Refuge. (This is likely related to the notion of entering sacred space.) Although the number of participants varied from week to week, an occasional female Sufi "dervish" (as she was described) from a nearby town would often be present. The dhikr ritual celebrant described the dervish as "more accomplished" or "more of a master" than she herself was.

The polygonal room that was the setting for the dhikr had been constructed in accordance with the specifications of "sacred geometry." It had an inspiring view, with windows in each of the segments looking out on the surrounding mountains. There was a green wall-hanging and a plaque in the room covered with golden Arabic script oriented in the direction of Mecca. Chairs and zafus were available for seating around the room's inner periphery. The female ritual celebrant (and some of the participants) donned a white bonnet, explaining that the ceremony itself was, in part, a celebration and recognition of the ninety-nine names of Allah—all of which were recited during the dhikr. Part of the ritual procedure included a manual containing readings, chants, and verses both in English and transliterated Arabic. The celebrant assigned each of the participants a reading (from the manual).

The performative elements of the dhikr consisted of chants—repetitions of single words like "Allah" or "hu" [a sacred word]—some of which repeated entire phrases. A portion of these were sung on a single 
pitch; others were sung melodically. Sometimes all sang in unison, and, at other times, a single participant chanted phrases and sentences from the ritual manual, while others simply repeated "Allah" or "hu" or some other syllable more softly in the background. At one point, the repetitions became so numerous and rhythmic that participants were drawn into an altered state of consciousness (ASC), with eyes half open, staring straight ahead with the head regularly swinging from side to side, and gentle swaying of the head with eyes closed. Thus, participants rhythmically moved their heads and bodies with eyes closed in a borderline trance state. The ritual celebrant instructed participants to repeatedly shift the movement of their heads from the left and then to the right and then down to their hearts as they recited some phrases over and over. Participants remained seated for this first part of the ritual performance while the celebrant announced short instructions about the next phase of the ritual, but she gently chastised another woman participant at one point when the latter began to offer longer explanations with the admonition "don't break the flow by intellectualizing" (cf. Csikszentmihalyi 1990). "Ritually induced states of consciousness contrast with the normally static and stable social life by providing a period of fluidity for transformation of social status and self-experience through liminal or transitional states. The ritual then resolves status ambiguity by marking the social transition and by producing feelings of unity and community" (Winkelman 2010, p. 87).

Following the seated part of the ceremony, participants arose, and, forming a small semicircle, faced Mecca. While the celebrant chanted verses from the manual, men and women gathered in different positions, standing across from one another. Participants made three, short coordinated bows to the left, the middle, and the right in rapid succession, all the while repeating "hu" and "Allah" over and over in the background. The ritual celebrant delivered a chant holding a large, round hand drum in her left hand and beating it in rhythm with her right hand. When the chanting had finished, participants cleared the space a bit while being instructed to join their left hands in the middle of the circle and to move their bodies in a counterclockwise circular motion leading with the right foot while moving to the left. Prerecorded music accompanied this circle dance. Participants then broke the circle and began dancing individually, using the left foot as a pivot while circling their bodies to the left. This was obviously part of the "whirling" so characteristic of the dervishes. As they danced individually, participants merged into a circle to the left, pivoting on the left foot while keeping the right hand up "toward heaven" and the left hand pointed down "toward the earth." The prerecorded music was then turned off and participants were instructed to gather in a semicircle, facing in the direction of the holy city of Mecca. Elevating and opening their hands, the dhikr ended with a litany of voiced blessings, while each participant softly and repeatedly chanted some syllable or name as background. Finally, we were asked to give each other a "Sufi kiss": grasping the hand of another participant and kissing the back of the hand. This officially ended the dhikr ritual.

\section{The Operational Dynamics of the Ritual Economy at the Refuge for World Truths}

\subsection{Commodification, Communication, and Consumption: The Building Blocks of a Ritual Economy}

How does the Refuge for World Truths sustain itself? How can we describe the functional dynamics of the heritage-scape, its modus operandi? Economics provides an initial entrée and frame of reference. The classical components of an economy are production, exchange (distribution), and consumption of goods and services. If we tweak the first two of these, rendering production as commodification and exchange/distribution as communication, while retaining the consumption label, we arrive at a description of the self-sustaining faith-and-heritage ritual economy undergirding the Refuge for World Truths.

\subsubsection{Ritual Commodification}

Ritual consists of words, gestures, and objects. However, as a performance, it may also take on the trappings of a commodity in certain contexts, especially if we use the designation of brand (cf. Cohen 1998). "New species of commodities (do-it-yourself kits, packaged vacations, entertainments, work-study programs) reflect the modern fragmentation and mutual displacement of work and 
leisure, and the emergence of new synthetic structures as yet unanalyzed" (MacCannell 1999, p. 7). "In marketing discourse, branding is understood to be precisely the mechanism whereby the experiences of consumers are integrated, their commitments are shaped and their world views are transformed. Branding is well positioned to be analyzed ... through the lens of ritual" (González 2015, p. 20). Most of the sacred centers at the Refuge for World Truths performed some sort of traditional ritual enactment, a "commodity" that interfaced with pilgrim visitors, "seducing" them (Di Giovine and Picard 2015) with the possibility of spiritual enrichment and the potential for self-transformation in the interests of identity consolidation.

\subsubsection{Ritual Communication}

Phylogenetically, it hardly seems necessary to state how important communication is to ritual: "Ritual is integral to vertebrate species, providing mechanisms for communication and social coordination ... Ritual is in essence a communication mechanism to enhance sociality of a species; this social focus to ritual has direct relationships to the well-recognized social enhancement functions of religion" (Winkelman 2010, p. 232). Adjusting our focus to individual experience and thus to a psychological perspective: "To understand religious transmission in any depth, we must envisage the mind not as a fixed generic device, such as a computer, but as a constantly developing organic structure whose capacity for encoding, processing, and recall is defined by patterns of prior experience and learning" (Whitehouse 2004, p. 27).

In one sense, of course, metaphorical communication is constantly coursing through the symbolism of a ritual performance. Agents staffing the sacred centers presided over the ritual performances at individual sites at the Refuge, thus communicating their authenticity: "[R]itualization often seeks to dominate non-ritualized space via schematically empowered ritual agents, who will experience and thus mold the non-ritualized environment according to their ritualized identity" (González 2015, p. 19). In another sense, the opportunity for ritual performance display itself needs to be advertised — communicated—to an interested public anxious to engage and consume its proffered commodity.

Thus, the benefits of a commodity-in this sense, a specific ritual performance-need to be communicated or, in economic parlance, exchanged among expectant constituencies and distributed more widely.

For religious communication to take place, potential exchange partners must be made aware of their mutual concerns, and informed about past episodes of service provision and future cooperation opportunities. Thus the proliferation of contemporary spirituality would be inconceivable without the marketing activities which transmit information between suppliers [commodifiers] and consumers. In other words, adequate conditions for the practice and fulfillment of contemporary spirituality only result from the symbolic, institutional and performative activities [read: ritual] on the supply side. (Hero 2014, p. 87)

Moreover, such ritual performance needs to communicate a sense of the tradition's authenticity: "[I]n order to survive, lifestyle brands must remain both distinctive and flexible enough that individual authenticity and authentic experience [read: heritage] can be expressed through the brand" (González 2015, p. 16).

\subsubsection{Ritual Consumption}

It is at this turn of the ritual economy that we can best assess the transformative effects that ritual performance and absorption has on the other as consumer.

Most ritual theories point to the fact that rituals do not merely reflect but produce particular religious attitudes and experiences. This is due to total sensory immersion in the religious context of the other, which awakens one to dimensions of religious life and experience that remain hidden when contact is only via written or verbal communication. (Cornille 2008, p. 164) 
Such immersion in and transformation by the performance of ritual undergirds and reinforces the brand label: "[B]rands can be understood as networks in which discrete nodal points (individual consumers) personalize corporate narratives or brand stories through their exercise of putative freedom" (González 2015, p. 30). Ritual "consumption" cycles back to reconsolidate the ritual's initial commodification, thus jump-starting the circulation of the ritual economy: "[C]ontemporary branding theory and practice incorporates the consumer directly into the brand narrative rather than attempting to speak to and persuade the consumer from the outside" (González 2015, p. 35).

Since the majority of these "commodified" ritual offerings took the form of retreats, devotions, or teachings, devotees were required to register and pay in advance for their presence and participation. Where actual payment for "ritual services" was not up front, pilgrims were strongly encouraged to make a goodwill donation to the organization. Thus, in a very substantive way, these pilgrim devotees provided financial support to each of the sacred centers, encouraging their continuity-that is, reconsolidating their commodification - by "consuming" their ritual offering. "Branding ... hopes to reconstruct consumer subjectivity, psychically, from the inside out, such that an anthropomorphism of brands is accomplished by consumers whose performances, both within and outside of the immediate brand context, automatically express the values and qualities associated with the brand, in circular fashion" (González 2015, p. 28).

\section{The Refuge for World Truths as a Sanctuary for Interreligious Dialogue and the Pursuit of Peace}

Initial research (1980s) at the site that was later to emerge as the Refuge for World Truths revealed growing pains (Raverty 2014). Many of the spiritual centers that are currently well established in the heritage-scape were at that time either undergoing construction or were absent from the scene altogether. Because of the focus of these early centers on the launch of their own foundations, the "silo effect" prevailed, and there was not a great deal of horizontal interaction among the initial establishments. Moreover, a substantial network of "born again" Christians dotting the local landscape signaled friction and disharmony. Harboring their own faith commitment, these individuals were suspicious of the couple inviting "alien" spiritual groups that were taking up residence in what they perceived as their territory, and the alterity these groups represented posed both a political and theological threat to the ensconced Christians. Rumors of Armageddon, the final battle between Christians and the "demonic forces" (aka the "others" and their spiritual groups) in the valley floated in the air. Although not commonplace, death threats against the newcomers and those who supported their arrival and establishment were very real. On the political side, what appeared as a contingent of the posse comitatus reared its head in the immediate vicinity, fearing that the supporters of the Refuge, especially the original entrepreneurial couple with their United Nations associations, were surreptitiously attempting to establish a "one-world government" in the region. Despite these potentially threatening undercurrents, nothing overtly destructive or violent emerged from the politically charged and religiously paranoid maelstrom.

Now that the Refuge for World Truths has emerged full-blown on the scene as an exceptional heritage-scape (a metaphorical and dynamic "museum"4), the political and religious climate in the region has changed considerably (Raverty 2014). I make the claim that, besides whatever scholarly contributions my ethnographic investigation makes, "it might also serve the more practical goal of promoting peace-as an alternative to violence—in today's complex and sorely troubled world." As a heritage-scape, the Refuge for World Truths today is uniquely positioned through the multiplicity of faith commitments and heritage identities for a more horizontal outreach to stimulate interreligious

4 “Just as a museum promotes new acquisitions and utilizes innovatively conceived 'blockbuster' expositions to both capture new demographics of visitors and encourage repeat visitation among one-time visitors, so too does expanding the diversity of sites within the heritage-scape provide opportunities for new and potentially repeat travelers to interact with the heritage-scape" (Di Giovine 2009, p. 363). 
dialogue and harmony, serving the goals of mutual understanding, universal respect, and global tolerance. After all, interreligious dialogue has surpassed the limiting model of reciprocal exchange between two interlocutors (as individuals or groups). Such dialogue now connotes an entire stance toward the "other," a way of engaging and processing alterity that originates in a faith commitment and extends to a celebration of heritage. In two of his letters, Dialogue and Mission (1989), and Dialogue and Proclamation (1991), the late Pope St. John Paul II expanded the scope and practice of interreligious dialogue to include (1) the dialogue of life, (2) the dialogue of action, (3) the dialogue of religious experience, and (4) the dialogue of theological exchange. Nor does such dialogue shy away from climate change, environmental degradation, and the preservation of shared life on our planet. Listen to a voice from the newsletter of the Haidakhandi Universal Ashram, ${ }^{5}$ one of the thriving spiritual centers at the Refuge:

On Saturday, July 20, there will be an Interfaith gathering followed by an Indian feast. Hanne Strong, who was given the vision to bring the world religions together, will help us open the ceremonies at 10 a.m. Other representatives of spiritual groups will share about their connection to Mother Earth and how they are serving Her ... We will spend the afternoon "harvesting" ideas from the morning programs and see how we can "integrate" and support them more at our centers. (Ramloti 2019)

In addition to share information via mutual exchange, the opportunity for commensalism and other types of "sharing" creates a setting promoting unity and goodwill: "This will be followed by Taiko drumming, dance, sharing of songs, poetry, and meditations celebrating the Divine Mother. We will all join together after this for another scrumptious Indian Feast" (Ramloti 2019). Nor was the Haidakhandi Universal Ashram the only spiritual center at the Refuge supporting mutual exchange in the context of a common feast: "Each year, the Crestone Mountain Zen Center, our next-door neighbor, has a large luncheon for the various spiritual groups and friends in Crestone. It is always such a treat to be together as we renew our friendships and share in the commonality of our practices" (Ramloti 2019). This comment by Elizabeth Mattis-Namgyel gets right to the point:

It was absolutely wonderful being at the Ashram this morning. Devotional practice just cuts through all the complications, and one's innate warmth and intelligence shines through in such a simple way. I rejoice that we are neighbors, and I marvel at how easy it is to cross over into each other's tradition, and that no adjustment need be made! The truth comes through in such a deep and natural way, doesn't it? (Ramloti 2019)

The opportunities for ritual immersion, interreligious dialogue, and the practices these give rise to bestow a ray of hope to those pilgrims who travel to the Refuge as spiritual seekers, both seeking and claiming faith, intent on personal transformation and renewal. In the words of one such pilgrim, "I always feel love and blessings here. The energy revitalizes one's core" (Ramloti 2019).

\section{Conclusions}

Despite rumors to the contrary, religion is far from disappearing in the wake of increasing secularization in our contemporary high-tech and mobile lives (Berger 2014). The quest for some sort of transcendent orientation, grounded in faith and revelation, giving meaning to life and anchoring one's identity amidst the multifarious material and empirical distractions and seductions of our twenty-first-century lives, has taken some twists and turns in recent history. New Age obsession with amalgamation lives side by side with traditions steeped in heritage-identity consolidation

5 A faith-and-heritage testimonial from one of its devotees: "The Ashram in Crestone is Awesome, a very sacred space on Sacred Land. It's the 30-year Birthday. I was there from the beginning, doing Karma Yoga with different groups to help build this wonderful retreat and place of Divine Prayer. This is one of the few places you can really experience the Divine Mother. She came from India blessed by Babaji and Muniraj. If you have never been there, join the Celebration" (Ramloti 2019). 
and self-recognition in the brand authenticity of spiritual traditions with well-established authority, geographical specificity, and historical depth.

The unique setting of the Refuge for World Truths offers a heritage-scape for pilgrim seekers intent on individual transformation and recapturing a grounded identity.

This is the heritage-scape, the social space of an imagined community linked together by their common appreciation and identification with cultural diversity. Like other communities, that of the heritage-scape gains materiality through these material monumental media who index and perform the new meta-narrative claim of "unity in diversity". (Di Giovine 2009, p. 37)

The ritual enactments offered by the organizational entities originally invited by its husband-and-wife team of "heritage defenders" to this "sacred" location extend a commodified performative interface to spiritual pilgrims that communicates a seductive message of immersion and identity transformation in public consumption of an array of ritual traditions.

Cohen (2010) spells out the "performative turn" undergirding this modern identity search:

Thus, while all performances are citations, or enacted ways of doing, for instance, class, sexuality, gender, ethnicity, age and abilities, identities are also performative in that they are negotiated in and through a process of becoming ... . The theatrical metaphor of "kinesis" offers insight into the performative nature of identity constitution as a process of "breaking and remaking" in which performances not only mirror and sustain normative boundaries but can also subvert and transgress them .... An understanding that identity is not a fixed given, but is always in process, indicates that experiences [e.g., ritual immersion] can be opportunities for individuals to (re)produce a sense of personal identity. (Cohen 2010, p. 34)

As witnessed at the I Am Harmony homestead, the Dragon Mountain Zen Temple dharma talks ("sermons"), and the Sufi dhikr, far from being mere passive participants in most of these proffered ceremonial enactments, such ritual "consumers" unassumingly mold the ritual contexts in the very act of performing them: "The sounds, actions, and drama evoke a different kind of insight-a somatic knowledge gained through displaying and observing ritual performance" (Joskovich 2016, p. 16). Moreover, the self-generating ritual economy they help set in motion through their participation serves to strengthen the "brand" of the original ritual commodification in its never-ending circulation: "Auto-communication is important even in public rituals. In fact, the transmitters of ritual messages are often, if not always, their most significant receivers" (Rappaport 1979, p. 178).

Thus, at the Refuge for World Truths, we are confronted with a heritage-scape, a panoramic site of ritual instantiations cycling in commodification, communication, and consumption that presupposes a faith commitment and answers the call of spiritual pilgrims looking for identity in religious fulfillment, seeking transformation under the guise of a range of authentic ceremonial performances. Taking our cue from one of the religious heritage traditions, "in Zen, awakening is not merely a mental or psychological state; rather, it is manifested in body, conduct, and actions. Realization is embodied in the enactment of the individual, and it becomes an inherent part of one's character" (Joskovich 2016, p. 18).

Faith undergirds the cultural heritage of those who claim a spiritual or religious path. Faith can be an important part amassing the assemblage of what we label cultural heritage, helps people to find an identity therein, and promotes a sense of ownership of one's traditional heritage brand. Or, in the words of Zaslow (2014, p. 38), "Tradition can be thought of as a spiritual connection-an energetic transfer-between what is old and what is emerging—all under the spell of divine inspiration."

Funding: This research received no external funding.

Acknowledgments: I wish to thank Saint John's Abbey, Collegeville, Minnesota (USA), with providing me the time and resources to complete this project.

Conflicts of Interest: The author declares no conflict of interest. 


\section{References}

Atran, Scott. 2012. How Can a Better Understanding of Sacred Values Help Us Resolve Intergroup Conflicts? Religion and Science Today. Available online: http://www.scienceandreligiontoday.com/2012/05/22/how-can-abetter-understanding-of-sacred-values-help-us-resolve-intergroup-conflicts/ (accessed on 10 October 2016).

Berger, Peter Ludwig. 2014. The Many Altars of Modernity: Toward a Paradigm for Religion in a Pluralist Age. Boston and Berlin: De Gruyter.

Berger, Peter Ludwig, Brigitte Berger, and Hansfried Kellner. 1973. The Homeless Mind: Modernization and Consciousness. New York: Vintage.

Bregman, Lucy. 2016. Spirituality: Unpacking a Glow Word. Interview by Betsy Johnson Miller. In Bearings Online, 23 November. Available online: http://collegevilleinstitute.org/bearings/spirituality-unpacking-aglow-word/ (accessed on 24 November 2016).

Cahoy, William. 2016. A Community of Disciples: How the Church Benefits from the Intentional Community Movement. Bearings Online. September 1. Available online: http://collegevilleinstitute.org/bearings/ community-disciples/ (accessed on 6 September 2016).

Casey, Michael. 2005. Strangers to the City: Reflections on the Beliefs and Values of the Rule of Saint Benedict. Brewster: Paraclete Press.

Cohen, Mark Nathan. 1998. Culture of Intolerance: Chauvinism, Class, and Racism in the United States. New Haven and London: Yale University Press.

Cohen, Scott. 2010. Searching for Escape, Authenticity and Identity: Experiences of 'Lifestyle Travellers'. In The Tourism and Leisure Experience: Consumer and Managerial Perspectives. Edited by Michael Morgan, Peter Lugosi and J. R. Brent Ritchie. Bristol: Channel View Publications, pp. 27-42.

Cornille, Catherine. 2008. The im-Possibility of Interreligious Dialogue. New York: Crossroad.

Csikszentmihalyi, Mihaly. 1990. Flow, The Psychology of Optimal Experience. New York: HarperCollins.

Csordas, Thomas, ed. 2009. Transnational Transcendence: Essays on Religion and Globalization. Berkeley: University of California Press.

Di Giovine, Michael. 2009. The Heritage-Scape: UNESCO, World Heritage, and Tourism. Lanham: Lexington Books.

Di Giovine, Michael, and David Picard, eds. 2015. The Seductions of Pilgrimage: Sacred Journeys Afar and Astray in the Western Religious Tradition. Ashgate Studies in Pilgrimage. London and New York: Routledge.

Dulles, Avery. 1983. Models of Revelation. Garden City: Doubleday.

Geertz, Clifford. 1973. The Interpretation of Cultures: Selected Essays. New York: Basic Books.

González, George. 2015. The Ritualization of Consumer Capitalism: Catherine Bell's Ritual Theory, Ritual Practice in the Age of Starbucks. Implicit Religion 18: 3-44. [CrossRef]

Griffin, Roger. 2012. Terrorist's Creed: Fanatical Violence and the Human Need for Meaning. London: Palgrave Macmillan.

Hero, Markus. 2014. The Marketing of Spiritual Services and the Role of the Religious Entrepreneur. In Religions as Brands: New Perspectives on the Marketization of Religion and Spirituality. Edited by Jean-Claude Usunier and Jörg Stolz. Ashgate AHRC/ESRC Religion and Society Series. Surrey: Ashgate, pp. 75-87.

Joskovich, Erez. 2016. Playing the Patriarch: Representation and Transformation in the Zen Sermon. Journal of the American Academy of Religion 85: 1-24. [CrossRef]

Lévi-Strauss, Claude. 1962. La pensée sauvage. Paris: Plon.

MacCannell, Dean. 1999. The Tourist: A New Theory of the Leisure Class. Berkeley and Los Angeles: The University of California Press.

McClinchey, Kelly, and Barbara Carmichael. 2010. The Role and Meaning of Place in Cultural Festival Visitor Experiences. In The Tourism and Leisure Experience: Consumer and Managerial Perspectives. Edited by Michael Morgan, Peter Lugosi and J. R. Brent Ritchie. Bristol: Channel View Publications, pp. 59-77.

Moritz, Joshua M. 2016. Science and Religion: Beyond Warfare and Toward Understanding. Winona: Anselm Academic. Polanyi, Michael. 1964. Science, Faith and Society. Phoenix Books. Chicago: The University of Chicago Press.

Rahner, Karl. 1976. Grundkurs des Glaubens: Einführung in den Begriff des Christentums. Freiburg: Herder.

Ramloti. 2019. Haidakhandi Universal Ashram Newsletter. June/July. Available online: https://www.babajiashram. org/single-post/2019/07/12/Ashram-Newsletter---JuneJuly-2019 (accessed on 1 August 2019).

Rappaport, Roy. 1979. The Obvious Aspects of Ritual. In Ecology, Meaning, and Religion. Edited by Roy Rappaport. Berkeley: North Atlantic Books, pp. 173-221.

Raverty, Aaron Thomas. 2014. Refuge in Crestone: A Sanctuary for Interreligious Dialogue. Lanham: Lexington Books. 
Raverty, Thomas Donald. 1990. Kristina: A Charismatic in the New Age. Ph.D. thesis, Department of Anthropology, The University of Minnesota, Minneapolis, MN, USA.

Rinpoche, Dzogchen Ponlop. 2014. Penetrating Wisdom: The Aspiration of Samantabhadra. Boston: Snow Lion.

Stolz, Jörg, and Jean-Claude Usunier, eds. 2014. Religions as Brands: New Perspectives on the Marketization of Religion and Spirituality. Ashgate AHRC/ESRC Religion and Society Series; Surrey: Ashgate, pp. 3-25.

Turner, Victor. 1967. The Forest of Symbols: Aspects of Ndembu Ritual. Ithaca: Cornell University Press.

Wallace, Anthony Francis Clarke. 1970. Culture and Personality, 2nd ed. New York: Random House.

Whitehouse, Harvey. 2004. Modes of Religiosity: A Cognitive Theory of Religious Transmission. Walnut Creek: AltaMira Press.

Winkelman, Michael. 2010. Shamanism: A Biopsychosocial Paradigm of Consciousness and Healing, 2nd ed. Santa Barbara: Praeger.

Wroblewski, Michael. 2014. Public Indigeneity, Language Revitalization, and Intercultural Planning in a Native Amazonian Beauty Pageant. American Anthropologist 116: 65-80. [CrossRef]

Zaslow, Rabbi David. 2014. Jesus: First-Century Rabbi. Brewster: Paraclete Press.

(C) 2020 by the author. Licensee MDPI, Basel, Switzerland. This article is an open access article distributed under the terms and conditions of the Creative Commons Attribution (CC BY) license (http://creativecommons.org/licenses/by/4.0/). 